\title{
Key issues and development direction of petroleum geology research on source rock strata in China
}

\author{
Jiarui Li, Zhi Yang ${ }^{\circledR *}$, Songtao Wu, Songqi Pan \\ Research Institute of Petroleum Exploration \& Development, PetroChina, Beijing 100083, P. R. China
}

Keywords:
Tight oil and gas
shale oil and gas
coal-bed methane
source rock strata
unconventional oil and gas
sweet area
Cited as:
Li, J., Yang, Z., Wu, S., Pan, S. Key
issues and development direction of
petroleum geology research on source
rock strata in China. Advances in
Geo-Energy Research, 2021, 5(2):
121-126, doi: 10.46690/ager.2021.02.02

\begin{abstract}
:
After more than 20 years of technological advancements, the novel field of oil and gas production from source rock strata, which comprise tight and shale oil and gas reservoirs, has become the major contributor to the increase in unconventional oil and gas reserves in China. Accordingly, this field has gradually entered a new stage of revolutionary development. The oil and gas production in China from source rock strata will achieve sustainable development in the future. Different types of source rock strata present distinct challenges and require diverse development paths. Based on the geological conditions of source rock strata in China, this study focuses on identifying the "sweet areas" among hydrocarbon accumulations. It specifically analyzes the key development issues of tight oil, tight gas, shale oil, shale gas, and coal-bed methane, while proposing potential solutions and identifying the possible directions for future development. This study aims to provide a reference for scientists concerned with the development of unconventional oil and gas reserves in China.
\end{abstract}

\section{Introduction}

Source rock strata can be used to obtain a continuous distribution of oil and gas resources that can be exploited industrially by using existing technologies, in which hydrocarbons are generated, retained, or gathered in the source rocks or in the tight reservoirs adjacent to the source rocks (Yang et al., 2019b, 2021). Oil and gas are derived from source rock strata using two types of resources: source rock reservoirs including shale oil, shale gas, and coal-bed methane (Yang et al., 2019a; Zou et al., 2019b), as well as tight oil and gas reservoirs adjacent to the source rocks (Yang et al., 2015; Sun et al., 2019). The overall strategic development of unconventional production of oil and gas in China is now being realized, with the utilization of source rock strata. Furthermore, the field of tight sandstone gas production has seen large-scale development (Dai et al., 2012; Sun et al., 2019). The need for an accelerated development of shale gas and tight oil reservoirs has garnered significant attention (Hao et al., 2013; Chen et al., 2015; Yang et al., 2015; Jin et al., 2016; Ma et al., 2018; Jiao et al., 2020; Xu et al., 2020; Horsfield et al., 2021; Venieri et al., 2021; Zou et al., 2021). Meanwhile, shale oil production has shown potential to allow further exploration ( $\mathrm{Du}$ et al., 2019; Yang et al., 2019c; Hu et al., 2020; Zhao et al., 2020; Zou et al., 2020), and manufacturing of coal-bed methane has demonstrated stable development (Sun et al., 2021). Overall, oil and gas derived from source rock strata have become major contributors for the increase in unconventional oil and gas reserves in China (Yang et al., 2021).

\section{Petroleum geology characteristics of source rock strata in China}

The core of hydrocarbon accumulation in source rock strata is the source rock. Within the strata, a large amount of oil and gas resources are gathered in the source rocks and in the tight reservoirs adjacent to the source rocks. The onshore source rock strata in China are characterized by varied sedimentary environments and complex lithofacies, ranging from the MesoNeoproterozoic to the Quaternary. The hydrocarbon accumulation distribution in the source rock strata can be roughly divided into Cenozoic, Cretaceous, Jurassic-Triassic, Upper

\section{Yandy Scientific} Press
${ }^{*}$ Corresponding author.

E-mail address: 347092254@qq.com (J. Li); yangzhi2009@petrochina.com.cn (Z. Yang); wust@petrochina.com.cn (S. Wu); psq2017@petrochina.com.cn (S. Pan). 2207-9963 (c) The Author(s) 2021.

Received March 5, 2021; revised March 13, 2021; accepted March 14, 2021; available online March 16, 2021. 


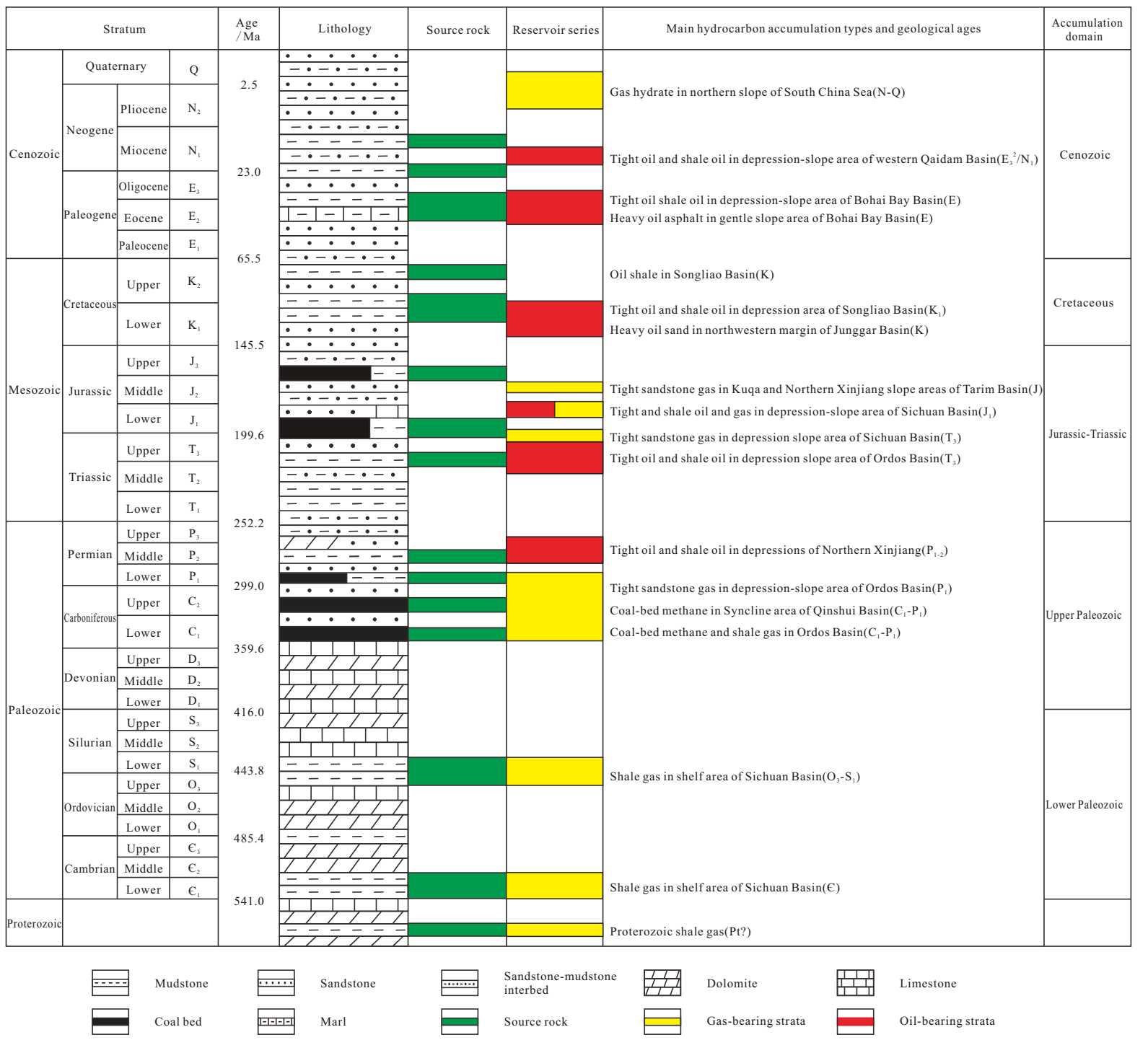

Fig. 1. Comprehensive histogram of unconventional oil and gas resources in China (Yang et al., 2021).

Paleozoic, and Lower Paleozoic accumulation domains (Fig. 1) (Yang et al., 2021). Among these, the Cenozoic is represented by tight oil and shale oil in the Paleogene strata of the Bohai Bay and Qaidam basins. The Cretaceous is represented by tight oil and shale oil in the Songliao Basin. The TriassicJurassic is represented by tight oil and shale oil in the Ordos Basin, tight oil and shale oil in the Sichuan Basin, and tight sandstone gas in the Tarim Basin. The Upper Paleozoic is represented by Carboniferous-Permian tight sandstone gas and coal-bed methane in the Ordos Basin and tight oil and shale oil in the Junggar Basin. The Lower Paleozoic is represented by Wufeng-Longmaxi Formation shale gas in the Sichuan Basin.

The study of oil and gas deposits in source rock strata in China is a new area of research in petroleum geology, which studies the types, occurrence mechanisms, enrichment laws, distribution characteristics, production mechanisms, assessment methodologies, key technologies, and development strategies of oil and gas resources in China's onshore source rock strata (Yang et al., 2021). The oil and gas derived from source rock strata are distributed continuously in the center and the slope area of the basin over a large range. Furthermore, the source rocks and reservoirs coexist without obvious trap boundaries, which breaks through the concept of conventional oil and gas reservoirs; consequently, the objective of the research shifts from "trap and reservoir" to "reservoir sweet area" (Zou et al., 2019b; Yang et al., 2021). The core focus in the research on the oil and gas geology of source rock strata is to study and evaluate the sweet area (section) of hydrocarbon accumulations in the source rock strata; that is, on the plane (section) of the source rock strata, artificially stimulations are induced throughout by using existing technologies to produce a favorable zone (section) that comprises industrial oil and gas deposits (Yang et al., 2021). The identification of the "sweet area" (section) is carried out using the product of the six-property relationship, which includes the source rock, reservoir, oil-bearing, liquidity, fracture, and economy. The source rock property represents the hydrocarbon generation potential and spatial distribution of high-quality source rocks; 
it is used to find organic-rich source rocks. The reservoir property represents the formation and distribution of lithology and lithofacies, reservoir capacity, and connectivity of pore throatfracture network systems in tight reservoirs, with the aim of finding effective reservoir development areas and screening sweet reservoir are as that exhibit relatively good porosity and permeability (Ijeje et al., 2019; Cai et al., 2020; Liang et al., 2021). The oil-bearing property represents the occurrence state and filling degree of oil and gas in tight reservoirs, with the aim of optimizing reservoirs with good oiliness. The fluidity property represents the formation energy, fluid composition, oil and gas quality, and the seepage-diffusionadsorption characteristics of tight reservoirs, with the aim of determining oil and gas reservoirs that exhibit strong mobility and can be easily exploited. The fracture property represents natural fractures, artificial fractures (stimulated throughout the network), and the stress characteristics of tight reservoirs, with the aim of optimizing high-brittleness reservoirs that facilitate large-scale fracturing. Finally, the economy property represents the real potential of oil and gas resources, lowcost development paths, and economic and social benefits; it aims to improve the efficiency of exploration and development under the premise of ensuring sustained production.

\section{Key issues in petroleum geology of source rock strata in China}

Currently, the development of oil and gas production from onshore source rock strata in China faces many issues and challenges, such as lack of theoretical understanding, technological research and development, and cost control; these factors seriously restrict the large-scale utilization and effective exploitation of source rock strata as oil and gas resources.

\section{Tight oil}

- The lithology of an onshore tight reservoir is complex and difficult to predict, while the stability and continuity of the reservoir distribution are poor.

- The degree of thermal evolution of onshore source rocks is low, oil viscosity is generally large, and oil fluidity in the reservoir is poor.

- The target layer is mainly under medium or low pressure, and generally requires energy storage and pressurization; therefore, it is difficult to develop this layer effectively.

- The degree of geology-engineering integration is low, while the applicability of key technologies still needs to be improved and the development cost is still high.

\section{Shale oil}

- The onshore shale strata are mainly in the medium and low maturity windows because of the low thermal evolution degree, low hydrocarbon generation conversion of organic matter under natural conditions, high oil viscosity, and low movable oil proportion.

- The porosity and permeability of shale reservoirs are extremely low. Inorganic pores in clay minerals function as the main reservoir storage; however, organic pores are generally underdeveloped, with poor storage and connectivity.

- The natural fractures in shale reservoirs are relatively low, and the content of plastic clay minerals is high; this renders the creation of artificial fractures difficult.

- The underground processing of shale oil is a physical and chemical process, in which the "horizontal well electric heating upgrading" technology is used to constantly heat the organic-rich shale intervals at buried depths ranging from $300 \mathrm{~m}$ to $3000 \mathrm{~m}$, thereby converting various types of organic matter into light fractions (Zhao et al., 2020). At present, there are still some uncertainties in the promotion of an underground in situ conversion processing technology that uses heating.

\section{Tight sandstone gas}

- The exploration targets of continental and transitional facies are deeper and more complex, and the natural gas accumulation patterns are changeable; therefore, it is difficult to find new sources of tight sandstone gas.

- It is difficult to optimize well patterns and design horizontal well trajectories because of the strong heterogeneity of gas-bearing sand body distribution and the significant number of uncertainties during reservoir prediction between wells.

- The percolation law of tight sandstone gas areas with different water cuts is complex, and the reserve production capacity is very low.

- Key technologies, such as reservoir reconstruction, need to be strengthened for adapting to the characteristics of low-grade tight sandstone gas areas and improving the single-well production.

\section{Shale gas}

- There are still many unknown aspects with regard to the basic geological understanding of organic-rich shale distribution, reservoir mechanisms, and shale gas enrichment laws of onshore and marine-onshore transitional facies.

- Except for the shale gas of the Wufeng-Longmaxi Formation in the Sichuan Basin and its surrounding areas, the multi-layer marine shale of the Cambrian and Carboniferous has not been fully discovered.

- Research on deep marine shale fracturing, atmospheric shale low-cost fracturing, fault and fracture prediction, big data, artificial intelligence, and other technologies still need to be strengthened, and anew three-dimensional development model of an artificially stimulated fracture present throughout the gas reservoir still needs further exploration and innovation.

\section{Coal-bed methane}

- Insufficient preparations for medium and low rank coalbed methane resource reserve areas.

- The production of single wells is low, while their inefficient development is a significant issue.

- The geological conditions are complex, while coal-bed methane exploration and development technologies are difficult to replicate.

- Underground coal gasification refers to the process of producing $\mathrm{CH}_{4}, \mathrm{H}_{2}$, and other combustible gases through in situ controlled combustion of coal in the strata with an appropriate engineering technology (Zou et al., 2019a). At present, there are still some uncertainties with regard 


\begin{tabular}{|c|c|c|c|c|c|c|}
\hline \multicolumn{2}{|c|}{ reservoir type } & $\begin{array}{c}\text { oil and gas } \\
\text { accumulation profile }\end{array}$ & $\begin{array}{c}\text { theoretical } \\
\text { understanding }\end{array}$ & key technology & $\begin{array}{c}\text { strategic } \\
\text { positioning }\end{array}$ & $\begin{array}{c}\text { representative } \\
\text { example }\end{array}$ \\
\hline \multicolumn{2}{|r|}{ oil shale } & & $\begin{array}{l}\text { The whole contains organic matter. The } \\
\text { organic-ichcl lithofacies of deep lake and } \\
\text { shallow lake in depression control the } \\
\text { distribution of oil shale with high oil }\end{array}$ & $\begin{array}{l}\text { Surface distillation and heating in- } \\
\text { situ conversion. }\end{array}$ & $\begin{array}{l}\text { Important resources } \\
\text { of oil shale }\end{array}$ & Huadian, Dunmi Basin \\
\hline \multirow{2}{*}{ shale oil } & medium and low maturity & & $\begin{array}{l}\text { The thick and large area organic-rich shale } \\
\text { contains organic matter and hydrocarbons } \\
\text { as a whole. } \\
\text { Organic-rich sections are oil-bearing and } \\
\text { distributed continuously. Rich and high }\end{array}$ & $\begin{array}{l}\text { Horizontal well electric heating and } \\
\text { other underground in-situ conversion } \\
\text { technology. }\end{array}$ & $\begin{array}{l}\text { Strategic replacement } \\
\text { resources of shale oil }\end{array}$ & $\begin{array}{l}\text { Chang 7 Member of Ordos Basin } \\
\text { Nenjiang Formation of Songliao } \\
\text { Basin }\end{array}$ \\
\hline & medium and high maturity & & $\begin{array}{l}\text { yield in fr: } \\
\text { lamina. }\end{array}$ & $\begin{array}{l}\text { Horizontal well cutting volume fract- } \\
\text { uring and large platform development. }\end{array}$ & $\begin{array}{l}\text { Important resources } \\
\text { of shale oil now }\end{array}$ & Qingyi Member of Songliao Basin \\
\hline \multirow{2}{*}{ tight oil } & mediu & & $\begin{array}{l}\text { The forn } \\
\text { distribul }\end{array}$ & \begin{tabular}{|l}
$\begin{array}{l}\text { Horizontal well complex fracture net- } \\
\text { work fracturing platform development. }\end{array}$ \\
\end{tabular} & \begin{tabular}{|l|} 
Important substitute \\
resources for tight oil
\end{tabular} & Permian in Junggar Basin \\
\hline & medium and low pressure & $.0 \cdot 0 \cdot 0 \cdot 0 \cdot 0 \bullet$ & $\begin{array}{l}\text { sweet area is enrichede and hightly productive } \\
\text { The stratum is gas-bearing and contin- }\end{array}$ & $\begin{array}{l}\begin{array}{l}\text { Horizontal well volume fracturing } \\
\text { to increase production. }\end{array} \\
\end{array}$ & $\begin{array}{l}\text { Impc } \\
\text { of tis }\end{array}$ & $\begin{array}{l}\text { Chang } 7^{1} \text { Chang } 7^{2} \text { oil layer in } \\
\text { Ordos basin }\end{array}$ \\
\hline \multirow{2}{*}{ tight gas } & ring gas layer & - 0 - & $\begin{array}{l}\text { uoussy distrtibuted, and the structural } \\
\text { peak is enriched and high -yielding. } \\
\text { The coal maseasures are gas-bearing and }\end{array}$ & $\begin{array}{l}\begin{array}{l}\text { Water control and drainage to enha- } \\
\text { nce recovery. }\end{array} \\
\end{array}$ & $\begin{array}{l}\text { stitute } \\
\text { ight gas }\end{array}$ & $\begin{array}{l}\text { Xujiahe Formation in central } \\
\text { Sichuan Basin }\end{array}$ \\
\hline & water-free gas layer & $\cdot 0 \cdot 0 \cdot 0 \cdot 0 \cdot$ & 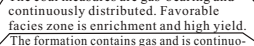 & $\begin{array}{l}\begin{array}{l}\text { Sand body characterization and ho- } \\
\text { rizontal well volume modification. }\end{array} \\
\end{array}$ & $\begin{array}{l}\text { Important resources } \\
\text { of tight gas now }\end{array}$ & Middle East Sulige, Ordos Basin \\
\hline \multirow{2}{*}{$\begin{array}{l}\text { coal-bed } \\
\text { methane }\end{array}$} & middle and low coal rank & o & 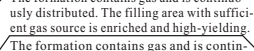 & $\begin{array}{l}\begin{array}{l}\text { Vertical well and other multi-well } \\
\text { fracturing production. }\end{array} \\
\text {. }\end{array}$ & $\begin{array}{l}\text { acement reso- } \\
\text { 1-bed methane }\end{array}$ & Cretaceous of Erlian Basin \\
\hline & middle to high & 00 & $\begin{array}{l}\text { uously distributed. Gass-filled and hyperto } \\
\text { nic zones are enriched and high-yielding. } \\
\text { The rich area of organic-rich laminated }\end{array}$ & $\begin{array}{l}\text { Vertical or cluster wells. Moderate } \\
\text { transformation of horizontal well } \\
\text { drainage gas development. }\end{array}$ & $\begin{array}{l}\text { Important resources of } \\
\text { coal-bed methane now }\end{array}$ & $\begin{array}{l}\text { Carboniferous - Permian in } \\
\text { Qinshui Basin }\end{array}$ \\
\hline \multirow{4}{*}{ shale gas } & onsho & 0 & $\begin{array}{l}\text { shale in deep water lacustrine basin is } \\
\text { high-yielding. }\end{array}$ & \multirow{4}{*}{$\begin{array}{l}\text { Horizontal well hydraulic volume } \\
\text { fracturing and platform "artificial } \\
\text { gas reservoir" volume development. }\end{array}$} & $\begin{array}{l}\text { ternative } \\
\text { f shale gas }\end{array}$ & $\begin{array}{l}\text { Da 'anzhai Segment, North- } \\
\text { central Sichuan Basin }\end{array}$ \\
\hline & transitional facies & $\mathrm{O}$ & $\begin{array}{l}\text { The organic-rich laminated shale in the } \\
\text { transitional deep water area is gas- } \\
\text { bearing and continuously distributed. }\end{array}$ & & $\begin{array}{l}\text { Important replacement } \\
\text { resources for shale gas }\end{array}$ & Shanxi Formation, Ordos Basin \\
\hline & \multirow[t]{2}{*}{ marine } & 0 & The organic-rich shale in the deep water & & \multirow{2}{*}{$\begin{array}{l}\text { Main resources for } \\
\text { shale gas production }\end{array}$} & \multirow{2}{*}{$\begin{array}{l}\text { Wufeng - Longmaxi Formation } \\
\text { in Sichuan Basin }\end{array}$} \\
\hline & & & & & & \\
\hline
\end{tabular}

Fig. 2. Theoretical understanding, key technologies and strategic positioning of unconventional shale strata oil and gas in China (Yang et al., 2021).

to the understanding of the mechanism for this process and the developments needed in the technical equipment.

In summary, the development of oil and gas reservoirs in different types of source rock strata faces different difficulties. For tight oil, the main challenge is the effective development of medium-and low-pressure parts; for tight sandstone gas, it is the effective utilization of water-bearing parts; for shale oil, it is the scaled development of medium and low maturity parts; for shale gas, it is the development of continental and marine-continental transitional parts; and for coal-bed methane, it is the supplementary development of low-rank coal. The next scientific and technological research phases will need to be further targeted for effectively solving these issues and maximizing the potential of these difficult-to-use resources (Fig. 2).

\section{Development direction of source rock strata oil and gas in China}

The source rock strata in China exhibit a rich accumulation of hydrocarbons. Natural gas in source rock strata will become the main force of natural gas production. Meanwhile, source rock strata will become the foundation of stable oil production, which have great development potential in the future.

\section{Tight oil}

- To carry out a new round of national classification evaluation of tight oil resources, the main enrichment zone for development needs to be selected and the "sweet area" that can be drilled must be identified.

- Research and development of applicable drilling and completion technologies are required to effectively cope with the low-and high-viscosity characteristics of onshore tight oil and to improve the production and recovery efficiency of single wells and blocks.

- To focus on the construction of tight oil national-level development demonstration zones in the Ordos, Songliao, and Junggar basins, a model for geology-engineering integration of different types of tight oils is necessitated to promote the exploration and development of tight oil across the country.

\section{Shale oil}

- The construction of a national-level demonstration area is necessitated for continental shale oil in the Qingshankou Formation in the Songliao Basin.

- To focus on the construction of the national demonstration zone of the Permian onshore shale oil in the Junggar Basin for medium-and low-maturity shale oil, there is a need to effectively cope with the characteristics of medium and low pressures, difficult seepage flow, and difficult reformation of the onshore tight oil layers, while exploring effective development paths for low-grade and difficult-to-use reserves.

- For organic-rich shale exhibit medium and low maturities, there is a need to focus on the construction of a national continental shale oil demonstration area in the seventh member of the Triassic Yanchang Formation in the Ordos Basin and the Cretaceous Nenjiang Formation in the Songliao Basin, while exploring the formation of core technologies and equipment for underground in situ conversion.

\section{Tight sandstone gas}

- To deepen the understanding of tight sandstone gas enrichment rules, optimization of resource evaluation methods, implementation of national selection evaluation, and large-scale application of new resources is necessitated.

- For the areas with water-bearing tight sandstone gas in Ordos, Sichuan, and other basins where reserves are difficult to use, the bottleneck theory and technological research must be strengthened, the organization and management models must be optimized, tight gas fiscal policies and tax subsidy reductions must be established, and the applicability of low-grade reserves must be maximized. 
- To develop key technologies such as high-precision, three-dimensional seismic, and large cluster horizontal wells, and to artificially stimulated fractures throughout the gas reservoir, intelligent engineering, improvement in the prediction accuracy of gas-bearing sand bodies, and increase in the production and recovery of single wells and blocks are necessitated.

\section{Shale gas}

- To strengthen the theoretical and technical research on the occurrence mechanism of non-marine shale gas, the Qiongzhusi Formation in the Sichuan Basin and other unbroken marine shale gas strata must be explored along with thin-bed precision drilling and effective fracturing. Furthermore, methods to achieve breakthroughs in new areas of shale gas extraction are required as soon as possible.

- The research and development of key technologies and equipment, such as the Wufeng-Longmaxi Formation marine deep shale gas volume fracturing technology and rotary steering tools, must be accelerated to support increase in production capacity.

- To establish a three-dimensional well pattern, a reasonable amount of well spacing and a production system template for marine shale gas blocks is required along with improved reserve production and block recovery for overall scale-benefit development.

\section{Coal-bed methane}

- The production and transformation tests must be consistent, as they promote stable production and increase the production in the old blocks of low-yield and lowefficiency coal-bed methane.

- The development of new production areas in the coalbed methane development demonstration test will be beneficial in low coal rank and complex structure areas.

- The production area must be expanded for growth in coal-bed methane production due to the comprehensive development of deep and coal-derived natural gas.

- The construction of the underground coal gasification test areas in the Ordos, Junggar, and Erlian basins is necessitated, along with the exploration of the formation theory and core technical equipment required for underground coal gasification.

Overall, hydrocarbon accumulation in the source rock strata in China has great development potential in the future. Drawing on the unconventional oil and gas development path of source rock strata in the United States and focusing on basic geological research and scale-benefit development of different shale rock strata, it is still necessary to continuously increase investment in theoretical models and technological research and development, enhance the strength of independent innovation, and promote the construction of talent teams and laboratories. Consequently, China's source rock strata oil and gas resources will be further consolidated, and reserves and production will achieve substantial growth. After studying and judging the future strategic development direction, it is suggested to focus on creating and developing three underground projects based on artificially stimulated fractures in the oil and gas reservoirs of source rock strata in China, namely: volume fracturing of oil and gas underground horizontal wells in source rock strata, in situ heating conversion processing of continental organic-rich underground shale, and in situ combustion gasification of the artificially stimulated fractures.

\section{Conclusions}

The focus of the source rock analysis is elucidating the sweet area selection and six-property relationship. These properties include the source rock, reservoir, oil-bearing, liquidity, fracture stimulation, and economy.

Targeted solutions to facilitate large-scale production and development of medium-and low-pressure tight oil, gas from water-bearing tight sandstones, low-rank coal-bed methane, continental and transitional shale gas, and medium-low mature shale oil are expected to be the key research directions for petroleum geology in China's onshore source rock strata over the next 15 years. If the sub-surface projects associated with two major ongoing underground projects based on artificially stimulated fractures in the oil and gas reservoirs, which involve in situ conversion processing of organic-rich shale into oil and gas and underground coal gasification, are successful, the strategic position of oil and gas source rocks will become even more important.

\section{Acknowledgement}

This work was supported by the National High Level Special Talent Support Plan (Fourth Batch), and the China National Science and Technology Major Project (No. 2016ZX05046).

\section{Conflict of interest}

The authors declare no competing interest.

Open Access This article is distributed under the terms and conditions of the Creative Commons Attribution (CC BY-NC-ND) license, which permits unrestricted use, distribution, and reproduction in any medium, provided the original work is properly cited.

\section{References}

Cai, J., Hajibeygi, H., Yao, J., et al. Advances in porous media science and engineering from InterPore 2020 perspective. Advances in Geo-Energy Research, 2020, 4(4): 352-355.

Chen, X., Fan, J., Zhang, Y., et al. Subdivision and delineation of the Wufeng and Longmaxi black shales in the subsurface areas of the Yangtze Platform. Journal of Stratigraphy, 2015, 39(4): 351-358. (in Chinese)

Dai, J., Ni, Y., Wu, X. Tight gas in China and its significance in exploration and exploitation. Petroleum Exploration and Development, 2012, 39(3): 277-284.

Du, J., Hu, S., Pang, Z., et al. The types, potentials and prospects of continental shale oil in China. China Petroleum Exploration, 2019, 24(5): 560-568. (in Chinese)

Hao, F., Zou, H., Lu, Y. Mechanisms of shale gas storage: Implications for shale gas exploration in China. AAPG Bulletin, 2013, 97(8): 1325-1346.

Horsfield, B., Zou, C., Li, J., et al. Prediction of the 
gas-generating characteristics of the Qiongzhusi and Longmaxi Formations, Yangtze Platform, southern China, using analogues. AAPG Bulletin, 2021, 105(5): 945-985.

Hu, S., Zhao, W., Hou, L., et al. Development potential and technical strategy of continental shale oil in China. Petroleum Exploration and Development, 2020, 47(4): 877-887.

Ijeje, J. J., Gan, Q., Cai, J. Influence of permeability anisotropy on heat transfer and permeability evolution in geothermal reservoir. Advances in Geo-Energy Research, 2019, 3(1): 43-51.

Jiao, F., Zou, C., Yang, Z. Geological theory and exploration \& development practice of hydrocarbon accumulation inside continental source kitchens. Petroleum Exploration and Development, 2020, 47(6): 1147-1159.

Jin, Z., Hu, Z., Gao, B., et al. Controlling factors on the enrichment and high productivity of shale gas in the Wufeng-Longmaxi Formations, southeastern Sichuan Basin. Earth Science Frontiers, 2016, 23(1): 1-10. (in Chinese)

Liang, W., Zhao, Y., Liu, J., et al. Advances in in-situ modified mining by fluidization and in unconventional geomechanics. Advances in Geo-Energy Research, 2021, 5(1): 1-4.

Ma, Y., Cai, X., Zhao, P. China's shale gas exploration and development: Understanding and practice. Petroleum Exploration and Development, 2018, 45(4): 589-603.

Sun, L., Zou, C., Jia, A., et al. Development characteristics and orientation of tight oil and gas in China. Petroleum Exploration and Development, 2019, 46(6): 1073-1087.

Sun, Q., Zhao, Q., Jiang, X., et al. Prospects and strategies of CBM exploration and development in China under the new situation. Acta Coal Sinica, 2021, 46(1): 45-76. (in Chinese)

Venieri, M., Pedersen, P., Eaton, D. Predicting Previous HitunconventionalNext Hit reservoir potential from wireline logs: A correlation between compositional and geomechanical properties of the Duvernay shale play of western Alberta, Canada. AAPG Bulletin, 2021, 105(5): 865-881.

$\mathrm{Xu}$, G., Yin, H., Yuan, H., et al. Decline curve analysis for multiple- fractured horizontal wells in tight oil reservoirs. Advances in Geo-Energy Research, 2020, 4(3): 296-304.

Yang, Z., Hou, L., Tao, S., et al. Formation condition and "sweet spot" evaluation of tight oil and shale oil. Petroleum Exploration and Development, 2015, 42(5): 555-565.

Yang, Z., Zou, C. "Exploring petroleum inside source kitchen": Connotation and prospects of source rock oil and gas. Petroleum Exploration and Development, 2019a, 46(1): 181-193.

Yang, Z., Zou, C., Fu, J., et al. Characteristics and "sweet area (section)" evaluation of continuous tight \& shale oil and gas in Ordos Basin, north-central China. Journal of Earth Sciences and Environment, 2019b, 41(4): 459-474.

Yang, Z., Zou, C., Wu, S., et al. Formation, distribution and resource potential of the "sweet areas (sections)" of continental shale oil in China. Marine and Petroleum Geology, 2019c, 102: 48-60.

Yang, Z., Zou, C., Wu, S., et al. From source control theory to source-reservoir symbiosis system: On the theoretical understanding and practice of source rock strata oil and gas geology in China. Acta Geologica Sinica, 2021, 95(3): 618-631. (in Chinese)

Zhao, W., Hu, S., Hou, L., et al. Types and resource potential of continental shale oil in China and its boundary with tight oil. Petroleum Exploration and Development, 2020, 47(1): 1-11.

Zou, C., Chen, Y., Kong, L., et al. Underground coal gasification and its strategic significance to the development of natural gas industry in China. Petroleum Exploration and Development, 2019a, 46(2): 205-215.

Zou, C., Pan, S., Jing, Z., et al. Shale oil and gas revolution and its impact. Acta Petrolei Sinica, 2020, 41(1): 1-12. (in Chinese)

Zou, C., Yang, Z., Zhang, G., et al. Establishment and practice of unconventional oil and gas geology. Acta Geologica Sinica, 2019b, 93(1): 12-23. (in Chinese)

Zou, C., Zhao, Q., Cong, L., et al. Development progress, potential and prospect of shale gas in China. Natural Gas Industry, 2021, 41(1): 1-14. (in Chinese) 